\title{
Discussion on the New Mode of College Students' Innovation and Entrepreneurship Club Construction
}

\author{
Jiping Pan \\ Panzhihua University, Sichuan, Panzhihua, 617000
}

Keywords: college students; innovation and entrepreneurship; club construction

\begin{abstract}
With the continuous development of the social development process, the "Internet + " era has provided ubiquitous opportunities for innovation and entrepreneurship for college students. Promoting mass entrepreneurship and innovation has become the "new normal" of current social development. This study points out the impact of the specific problems on the construction of the club by pointing out current situation of management mechanism and the construction of the management institutions in colleges and universities. This paper proposes a new model for the construction of college students' innovation and entrepreneurship clubs, introduces a new type of club management mechanism, explores more ways to build an innovative and entrepreneurial club that can better fit the actual situation of college students and integrate regional industries, and promote the further development of mass entrepreneurship and innovation.
\end{abstract}

\section{Introduction}

The development background trend of “mass entrepreneurship and innovation” provides a broader space for entrepreneurial development for college students in major universities to establish innovation and entrepreneurship, and establishes college students' innovation and entrepreneurship clubs [1], which is now the inevitable place. Then how to ensure the construction and normal operation of the innovation and entrepreneurship club, based on the broad sense, there is no corresponding regulation, and the professional direction between the universities is also different, and there is a big difference between the various departments. There is no unified understanding of the development of entrepreneurial and entrepreneurial work. The progress model of innovation and entrepreneurship clubs in most colleges and universities is relatively slow, and there is no corresponding construction model. Therefore, based on the current economic new normal background, the current situation of the construction of innovative and entrepreneurial clubs for college students, the lagging management mechanism and low operational efficiency [2], put forward the feasibility considerations based on the current club construction model. It is hoped that this research can provide reference for the construction of college students' innovation and entrepreneurship clubs.

\section{Current Status of Innovation and Entrepreneurship Education in China}

The teaching concept of mass entrepreneurship and innovation has been widely concerned by the public masses. Entrepreneurial innovation is a process of deepening from the surface to the inside, and now it has formed a good atmosphere of entrepreneurial innovation, and it has a top-down character. In the "Guiding Opinions on Developing Massive Space to Promote Public Innovation and Entrepreneurship"[3], it is clearly stated that: by 2020, a new type of entrepreneurial service that can effectively meet the needs of mass innovation and entrepreneurship and possess strong professional entrepreneurial service capabilities will be formed. Premier Li Keqiang also stressed that college students are the main force in implementing innovation-driven strategic development, mass entrepreneurship, and innovation. Colleges and universities are also an important discovery base for talent cultivation and technological innovation.

In recent years, the development of entrepreneurial clubs for college students has been increasing like mushrooming [4]. According to the statistics of relevant institutions [5], as of 2016, the 
National College Student Science and Technology Pioneer Park has reached more than 280, and the total area of the Pioneer Park has reached 10 million square meters. A total of nearly 9,000 entrepreneurial projects have been introduced, and nearly 5,000 have been launched. The graduated company has cultivated hundreds of thousands of entrepreneurial talents. The establishment of college students' innovation and entrepreneurship clubs is built on the teaching resources of colleges and universities, and to a certain extent, promotes their sustainable development. However, due to the innovation and entrepreneurship clubs of college students and the university science and technology entrepreneurship park, they are still new in the current social development. The construction time is relatively short, and the universities have not unified the construction management experience of such management institutions. At this stage, the construction and management mode of college students' innovation and entrepreneurship clubs is relatively lagging behind, and there is no further systematic improvement.

\section{Problems in Construction Management of College Students' Innovation and Entrepreneurship Club}

The college students' innovation and entrepreneurship clubs in major universities have not set up special management departments, nor have they established special club management institutions and a clear division of responsibilities. For example, in universities in Guangxi and other regions, the vast majority of college students' innovation and entrepreneurship clubs are entrusted by the employment management department of the school. Some colleges and universities are fully responsible for the school's academic affairs department, and some universities have separate management models of innovation and entrepreneurship [6]. For example, the above management mode, if the overall cooperation between the various departments is not strengthened, it will inevitably lead to the mutual responsibilities of the various departments of the club, reducing the overall work efficiency. According to the statistical research results of relevant departments, it is found that $35.51 \%$ suggest that schools should set up a special college innovation and entrepreneurship club construction management department, but the vast majority are only imaginary. Nor has it created a unified club management operation mechanism, and the management model is relatively simple, and it is impossible to achieve a clear division of responsibilities of the club.

In the process of building entrepreneurial and innovative clubs, college students usually take the lead in the school and assign the club to students to achieve specific construction, operation and management [7]. For example, in the vast majority of colleges and universities, there is a serious lack of specialized club management personnel. Only some students manage the daily affairs of the club, and many activities are planned by students. Under the current situation that the club special management staff is too lacking, the management mode of the club is also the responsibility of the students. Although it improves the entrepreneurial innovation management ability to a certain extent, it restricts the operating efficiency of the club. At the same time, the management core of the club is to ensure the normal operation of the club, ignoring the targeted guidance on various aspects such as facility configuration, entrepreneurship screening, information decision support, risk prevention and control. This situation has an impact on the professionalism of the innovation and entrepreneurship club. The lack of professional entrepreneurial tutors to guide, to a certain extent, also increases the overall project risk and restricts the work of the club.

The management mechanism of college students' innovation and entrepreneurship clubs is a member of the club. In the specific operational activities of the club, the relevant regulations must be observed. The formation of the management mechanism mainly includes the design of the organization, the clear division of the functions of the club, and the professional management. Documents such as mechanisms and job occupations are described [8]. The school manages directly through the school through the establishment of a dedicated innovation and entrepreneurship club management office. And configure the corresponding staff, responsible for the daily affairs of the club. However, most of the innovative and entrepreneurial clubs have not established a special club organization. Under such conditions, the daily operation management mechanism is relatively lack 
of systemicity, resulting in various management loopholes in the series of affairs of the club. .

The management mechanism of the admission project is different from the daily operation management of the club. Generally, it should have an integrated management project process. At the same time, it should also clarify the specific audit, operation management and main evaluation mechanism of different projects. For example, the risk assessment mechanism of innovative entrepreneurial projects is relatively imperfect, leading to the vast majority of students' entrepreneurial practice, neglecting the management of entrepreneurial projects, ignoring the changes in the social market environment, and building risk assessment mechanisms is particularly important.

\section{The Implementation Path of the Construction Mode of College Students' Innovation and Entrepreneurship Club}

In order to ensure the sustainable development of college students' innovation and entrepreneurship clubs, it is necessary to ensure the integrity of the organization and management institutions, but also need to be highly valued by the school. The work of the Innovation and Entrepreneurship Club is a whole-house work involving many factors. Only by building a sound organization management organization and taking the entrepreneurial and innovative talents as the core goal, we will build a university entrepreneurship center. The component entrepreneurial innovation club construction management team will carry out entrepreneurial innovation work in the whole hospital. Relying on the University Student Entrepreneurship Center, the College Student Innovation and Entrepreneurship Club was established In this process, it is possible to gradually develop a training mechanism in which the university student entrepreneurship center is the main guiding institution and the multi-institutional department coordinates, and carry out all aspects of entrepreneurial innovation work.

It is necessary to fully understand the actual situation of colleges and universities, formulate targeted construction programs for college students' innovation and entrepreneurship clubs, and ensure the development of various mechanisms of the club, target tasks, project sites, project funding, entrepreneurship teaching courses, team building and other aspects. Clarify the core objectives of the innovation and entrepreneurship club. The problem of the university students' innovation and entrepreneurship clubs is mainly to solve the problem of "four nos and four shortages" in the cultivation of entrepreneurial talents, and to determine whether there is a lack of entrepreneurial awareness and innovation ability. Construct a new type of entrepreneurial innovation club system with extracurricular and intra-class integration, practice and theoretical integration, narrow sense and broad integration. College students' innovation and entrepreneurship clubs should pay attention to the management of organizational formation, operation, goals, tasks, institutions, funding, etc., and clarify the construction goals and evaluation indicators.

Targeted assessment incentives should be developed based on the multi-faceted construction needs of the Entrepreneurship Innovation Club, including targeting club teams and club members, managing responsible instructors, and different targeted mechanisms between departments. Through the use of public defense methods, many relevant departments and members of the public are invited to serve as judges of the club's entrepreneurial innovation to ensure the connection between the club and the market. At the same time, it is necessary to strengthen the market adaptability between projects, to ensure that the results of the defense can be more transparent and open, regular assessment, and students and responsible persons who have achieved excellent results can be rewarded accordingly. At the same time, it is necessary to pay attention to the team building of the mentor, give the government, enterprises and other channels, invite professors with professional ability, serve as the assistant mentor of the entrepreneurial innovation club, and give targeted help and guidance to the university students' innovation and entrepreneurship club. The University Student Innovation and Entrepreneurship Club is a multi-departmental coordination mechanism. It is necessary to ensure that all departments can cooperate with each other to ensure the operation of the club's projects.

In order to carry out college students' innovation and entrepreneurship education, colleges and 
universities should pay attention to the talent training mode and the overall teaching content, deepen the curriculum teaching reform, and integrate entrepreneurship education into the professionalization and cultural quality education. Deepen the reform of the curriculum teaching system, and enable entrepreneurship education to be accommodated in specialized teaching to realize the cultural literacy teaching and credit system. You can open SYB's entrepreneurship course for all college students, adopt 2+2 credit system teaching mode, realize two compulsory credits for entrepreneurship courses, and carry out innovative and entrepreneurial teaching work. It is necessary to always focus on entrepreneurial atmosphere, entrepreneurship courses and entrepreneurial practice. Different parts of entrepreneurship training are detailed. Form a unified innovation and entrepreneurship education system, set up a specialized high-quality entrepreneurship education team, and effectively improve the overall level of entrepreneurial innovation teaching.

In the process of building college students' innovative and entrepreneurial clubs, it is necessary to ensure multi-faceted construction guarantees. Including the construction of hardware environment, colleges and universities should attach importance to college students' innovation and entrepreneurship clubs, and they can have independent and independent project control sites. The specific venue size can be formulated according to the actual situation. At the same time, we should establish a sound regulatory mechanism to ensure that it is connected with the enterprise, achieve standardized training in many aspects, and formulate corresponding project management methods to ensure that innovation and entrepreneurship can run smoothly. In addition, college students' innovation and entrepreneurship clubs should also ensure funding support and professional base construction, and fully utilize various resources to obtain funding and policy support. In addition, we must build a corresponding information exchange service platform, maintain a certain degree of contact with relevant government departments, enterprises and different institutions of the mentor, comprehensively understand the relevant information of the entrepreneurial team, and carry out a comprehensive innovation and entrepreneurship club team and Communication between external markets.

\section{Conclusion}

At present, the construction mode of college students' innovation and entrepreneurship clubs is relatively contradictory, mainly due to the lack of organizational structure, lack of management mechanism, and lack of professional supervisors. Therefore, on the one hand, it can speed up the system management mechanism of college students' innovative and entrepreneurial college students, realize the institutionalized management to achieve constraints and overall guidance, and effectively improve the overall management efficiency of college students' innovation and entrepreneurship clubs. The construction of the entrepreneurial club is still in an initial stage of exploration. It is necessary to continuously summarize relevant experiences and gradually improve it in the construction and management of the entrepreneurial innovation club. By proposing a new model for the construction of college students' innovation and entrepreneurship clubs, and introducing a new type of club management mechanism, we will explore more ways to build an innovative and entrepreneurial club that can better fit the actual situation of college students and integrate regional industries, and promote the further development of mass entrepreneurship and innovation.

\section{References}

[1] Han Xuehui. A New Mode of College Students' Innovation and Entrepreneurship Education in the Age of "Internet +"[J]. Journal of Chongqing University of Science and Technology (Social Science Edition), 2015(12): 54-56.

[2] Mei Yingying, Xia Fei. Constructing a New Mode of College Students' Innovation and Entrepreneurship Ability__From the Perspective of Public Welfare Entrepreneurship [J]. Jiangsu Higher Education, 2016(3): 114-116. 
[3] Chen Qingyue, Liu Ping. Research on the Management System of College Students' Innovation and Entrepreneurship Club [J]. Chinese University Students Employment: Theoretical Edition, 2016(6): 55-59.

[4] Liang Kunlun. The status quo and model innovation of innovation and entrepreneurship education in colleges and universities under the new normal [J]. Journal of Huanghe University of Science and Technology, 2015, 17(6): 116-118.

[5] Wen-Hai X U, Cao J. A Probe into the Innovation of Entrepreneurship Education in Higher Vocational College [J]. Theory \& Practice of Education, 2014.55

[6] YU Junjun, ZHANG Jinbo, Lü Pengju. Analysis on the Construction of New Mode of College Students' Innovation and Entrepreneurship Education under the Era of Internet $+[\mathrm{J}]$. 才, 2017(26).

[7] Zhang C, Si Y, Zhang Z, et al. A Probe into Innovation and Entrepreneurship Education in the "Internet+" Age -Based on "Internet+" Innovation and Entrepreneurship Competition for College Students [J]. Journal of Higher Education, 2017.

[8] Ren Shaowei, Yang Jian, Chen Wei. Exploration and Practice of College Students' Innovation and Entrepreneurship Education Model Based on Collaborative Innovation [J]. Journal of Changchun University of Science and Technology: Social Science Edition, 2015(12):147-151. 